\title{
人工歯根の表面改質
}

\author{
吉成 正雄・井上 孝* \\ 東京歯科大学口腔科学研究センター曾科理工学檴座 261-8502 千葉県千葉市美浜区真砂 1-2-2

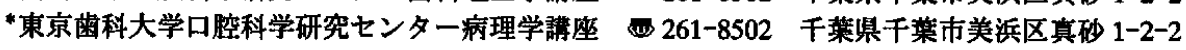

(1999 年 5 月 18 日受理)

\section{Surface Modification of Dental Implants}

\author{
Masao YOSHINARI and Takashi INOUE* \\ Department of Dental Materials Science, Oral Health Science Center, Tokyo Dental College \\ 1-2-2 Masago, Mihama-ku, Chiba 261-8502
}

*Department of Pathology, Oral Health Science Center, Tokyo Dental College, 1-2-2 Masago, Mihama-ku, Chiba 261-8502

(Received May 18, 1999)

\begin{abstract}
Dental implants require mechanical compatibility such as strength and wear resistance as well as surface compatibility with a host tissue in order to reduce their impact as foreign bodies. To satisfy these two requirements, it is preferable to utilize metal surfaces modified with functional ceramics, polymer materials or proteins. Since dental implants are used in contact with various tissues, it is necessary to have optimum surface compatibility with the host bone tissues, subepithelial connective tissues and epithelial tissues. Furthermore, dental implants are required to remain plaque-free at the surface exposed to the oral cavity. Such materials can be created under well-controlled conditions by modifying the surface topography and surface chemistry of metals that are in contact with those tissues.
\end{abstract}

\section{1.はじめに}

天然來人工歯根（以下，雬科インプラントと記述）

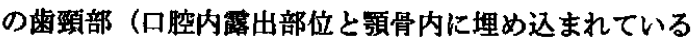
部分との境界）を Fig. 1 に示す。天然崡は上皮 (epithelium）が付着上皮（junctional epithelium）を介して enamel と結合しており組蟣が連続性をなしている。さらには， 咬合時などのショックをやわらげる物理的機能，血管を 介して栄養を供給する機能，および各組織の再生機能を 有する菌根膜（periodontal membrane）を持っている。歯 科インプラントは非自己であるばかりか, 天然歯のよう な巧妙な仕組みを持っていないため, 常に「異物排除」 の危険性にさらされている。このような厳しい条件下に ある歯科インプラント治㙩を成功させるには, 骨組織や 軟組織に接する部位や口腔内へ露出している部位に適合 した表面が求められる。

それぞれの組織の生体反応はインプラント材の「表面

E-mail: yosinari@tdc.ac.jp
形状」および「表面性状」に影㫪される。表面形状は細 胞の伸展・配列や細胞付着に関係する細胞動態を大きく 支配する1”。一般に鏡面よりは粗面のほうが細胞の付着 力が大きいが，その影揰は個々の細胞によって異なる。 細胞が基材の研磨溝に沿って配列するといういわゆる Contact guidance の付与は, 表面形状の制御の一形態で ある。それだけでなく，表面粗さは細胞の発現形態に重 要な役割を果たすといわれている。表面性状は表面の洏 れ性や荷電状怨などが関与し，生体材料とタンパク，バ クテリアあるいは細胞の吸着現象に影篅を与える。これ は, 接触角, および zeta 電位, 等電点などの界面動電 位, あるいは比誘電率, 摩撩係数などを測定することに より評価される。また，材料の矿食性，溶解性は細胞の 変性や壊死（necrosis）に関与する重要な性質である。

本稿は先ず, 臨床で使用されているチタンインプラン トおよびリン酸カルシウムコーティンダ・インプラント の現状を述べ，それらの欠点を克服すべく現在研究中の 表面改筫法について詳述する。最後に，インプラント材 の将来展望として「組織適合型インプラント」および「歯 


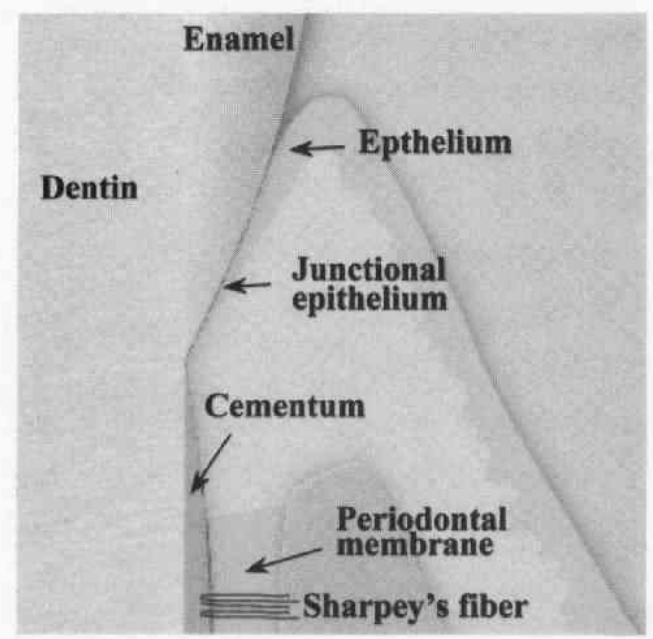

Natural teeth

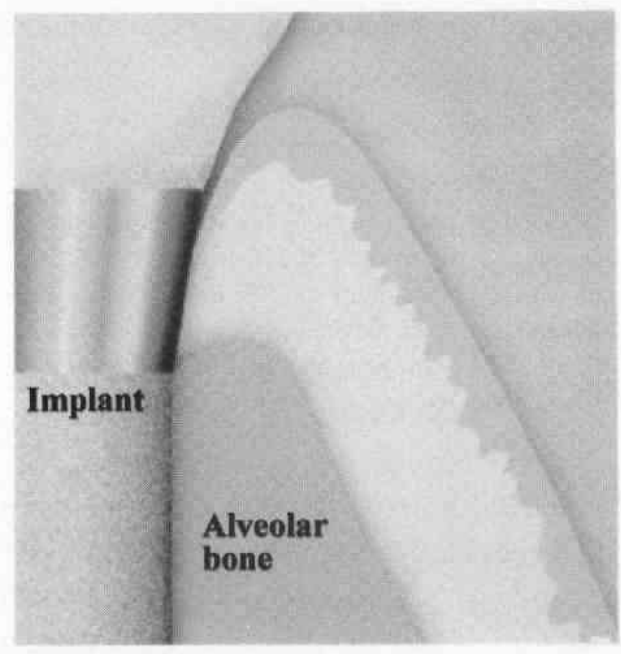

Dental implants

Fig. 1 Structural differences between natural teeth and dental implants.

根膜再建型インプラント」 ${ }^{21}$ に関して若干の解説を加え る。

\section{2. チタンインプラントの表面改質}

1）チタンインプラントの osseointegration

チタンが現在のインプラント材の主流をなしているの は, 他の金属材料と比較し osseointegration（骨結合）し 易いことにある。この理由として，当初はチタン表面に 生ずる強固な酸化膜が関係しているとされたが，現在で はアナターゼ型酸化物あるいはチタニアゲルのような反
応性に富むチタン表面が形成され，リン酸カルシウムや 血清タンパクが吸着しやすいためではないか，と考えら れている。チタンへの血清タンパクの吸着メカニズムは 以下のように説明されている3 4) (Fig. 2)。チタン表面 の酸化物と血清タンパクは $\mathrm{pH}=7$ ではともに負に带電 し，互いに反発するはずであるが，図左上に示すように， $\mathrm{Ca}^{2+}$ などの 2 荷の正イオンが両者の橋渡しをすれば両者 は吸着する。また右上に示すように, Ti 表面に吸着し たターミナル OH 基は正の電荷を持つことから負の血清 タンパクが吸着することも考えられる。

しが, チタンインプラントの osseointegration は, 骨とチタンが直接的に結合しているのではなく，界面で の中間層の形成により行われていることが明らかとなっ ている。解川らは $50 \mathrm{~nm}$ 程度の Ti 膜をエポンにコーテ イングして電顯観察を行い, インプラント周囲に起こる 現象を次のように推測している5（Fig. 3)。すなわち, チタンインプラント埋入初期には, $\mathrm{Ti}_{-} \mathrm{TiO}_{2}-\mathrm{TiOH}-\mathrm{Ca}-\mathrm{Oc}$, Op (骨性蛋白)-Osteoblast (骨芽細胞)-Oc，Op-Collagen 緎 維-骨(Bone)の層構造であったものが，時間の経過とと もに, $\mathrm{Ti}-\mathrm{TiO}_{2}-(\mathrm{TiOH})$ - proteoglycan (タンパク多糖複合 体)-Osteoid(類骨; 石灰化前の骨組織)-Bone の構造とな って osseointegration が獲得されると考えられている。

このように Ti インプラント材は, 界面に proteoglycan のような無定型構造物を形成して接合が行われるため骨 と直接結合しない。また，後述のリン酸カルシウムと比 較して骨形成速度が遅いことが指摘されている。さらに， $\mathrm{Ti}$ および $\mathrm{Ti}$ 合金からのインプラント周囲への金属イオ ンの溶出が報告され，悪条件が重なれぱ osseointegration が失われる危險性を持っている。バクテリアのサイス $(0.5 \mu \mathrm{m}$ 程度) 以上のギャッブが生ずれば，感染による 脱落の危険性が增す。

2）チタンの表面改質法

上記チタンの欠点を克服するために応用化がなされた のがリン酸カルシウム系セラミックス(Ca-P)であった。 Hydroxyapatite $\left[\mathrm{Ca}_{10}\left(\mathrm{PO}_{4}\right)_{6} \cdot(\mathrm{OH})_{2}\right]$ を代表とする Ca-P は, in vivo（生体内）においては, 初期骨形成能が大き く, 骨と直接結合する長所を有する。in vitro（生体外） 試験においても，骨形成に関与する蛋白や細胞外基質を 多く生成することなどが確認されている。このように， Ca-Pは骨形成に有利であるが，強度不足で単独では使 用できない。このような背景からチタンに Ca-Pをコー ティングした材料が開発され，臨床に使用されている。 Ca-P コーティング膜は当初ブラズマ溶射法により作製 されてきた。しかし，この材料は骨形成速度が大きい長 所を有する反面，コーティング膜とチタンの界面あるい は膜内部での破壊が生じ，マクロファージの食作用によ 

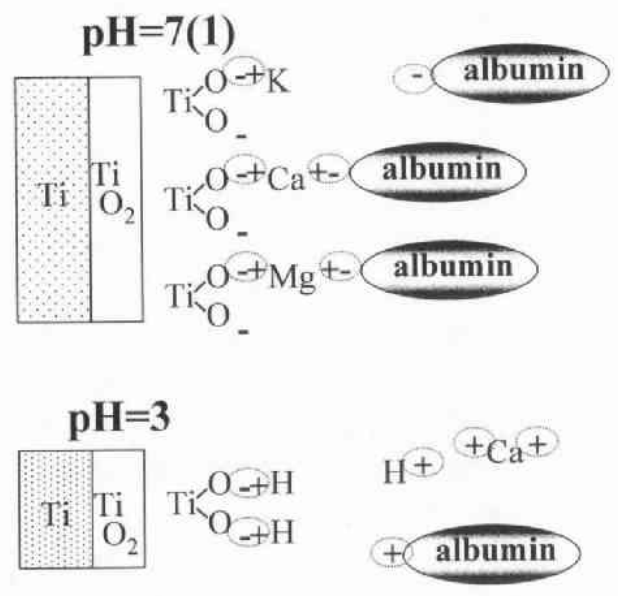

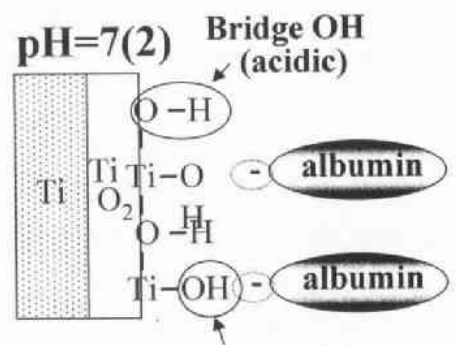

Terminal $\mathrm{OH}$

(basic)

Fig. 2 Mechanism of adsorption of human albumin to titanium.

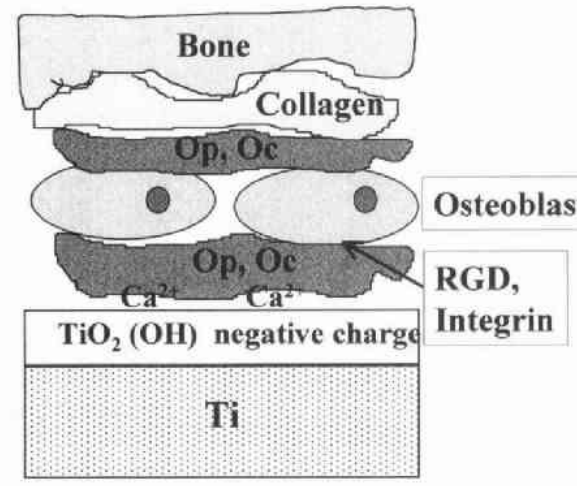

Early implantation stage

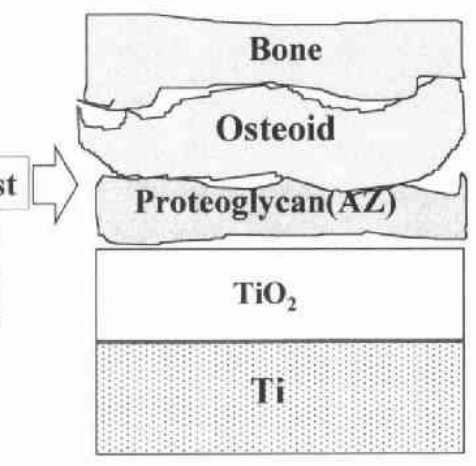

After osseointegration

Fig. 3 Osseointegration of titanium implant.

り炎症反底が起こる危険性があるとの指摘がなされてい る。この膜剥離はまた, 柬周ボケットで容易に生ずる $\mathrm{pH}=6.0$ の生理食塩水中での溶解性詿呀においても確認 されている゙。ここれらの原因は，プラズマ溶射法による コーティング膜が, $50 \mu \mathrm{m}$ 以上と比較的厚く, 膜組成が 不均一で，膜内部が粗造であるためと考えられている。

そこで最近、プラズマ溶射法に代わる新しいCa-P膜 コーティング技術，特に薄膜形成法が検討されている。 生体材料にとって薄膜は, 予め付与した表面形状を変化 させない，薄膜を介して機能性物質を固定できる，など の意義を持つ。また，密着性のよい緻密な薄膜を形成す ることにより膜剥離の危険性が減少し，プラスマ溶射に よるコーティング膜の欠点を補う有奻な手段となりう る。それらについて以下に順に解説する。
（1）生体内アパタイト析出法

(1)カルシウムイオン注入法 ${ }^{7}$

Ca イオン注入法は高エネルギーで Caイオンを金属表 面に照射し，表面を改質する方法であり，これによりチ タン表面の Ca-P 析出は急速に加速され, 骨棣組織の形 成はチタンよりも速いと報告されている。この表面改䫟 層の厚さは約 7〜10 nm であり, 表面に $\mathrm{TiO}_{2}, \mathrm{CaTiO}_{3}$, あるいは $\mathrm{CaO}$ が形成されるといわれている。 $\mathrm{CaTiO}_{3}$ は $\mathrm{TiO}_{2}$ より正に带電しており, 負の電荷を持つタンパク の吸着が速いことが予想される。

(2)チタニアゲル生成法

チタンをアルカリ水溶液に浸漬した後に加熱処理を行 ったり、 $\mathrm{TaCl}_{2}$ や $\mathrm{SnCl}_{2}$ を含む $\mathrm{H}_{2} \mathrm{O}_{2}$ 溶液でチタンの表面 処理を行うことにより, 表面にチタニアヒドロゲルを形 成する。その結果, 溶出したアルカリイオンが周囲の液 
のアパタイトに対する過飽和度を高め, 表面のゲルがア パタイトの核生成を誘起して, 表面にアパタイトが迅速 に形成されるものである。

これらの方法は，表面改質層が基材そのものなので膜 の剥離の危険性はないが, 生体内でのアパタイト析出に 時間を要し骨形成速度が遅れること, 骨との結合強度が 小さいことが榡念されている。

（2）リン酸カルシウム薄膜予借形成法

(1)ドライプロセス法

ドライプロセス法は, 半導体産業で汎用されている薄 膜形成法であり, lon sputtering 法, Ion plating 法, Ion beam dynamic mixing (IBDM) 法などが利用され, 密着性の 良い数 $\mu \mathrm{m}$ 以下の Ca-P 薄膜が形成可能である゙。このう ち, 物理的蒸着法とイオン注入法とを組み合わせた IBDM 法は $1 \mu \mathrm{m}$ 程度の厚さなら密着力の優れた膜が形 成できる。このIBDM 法により，Caイオンを注入しな がらリン酸カルシウムをコーティングすると, 膜は緻密 で薄いため透明である ${ }^{10)}$.Fig.4 に従来のブラズマ溶射 法（左）とIBDM法（右）によるコーティング膜の断 面図を示寸が，プラスマ溶射法では膜厚が $100 \mu \mathrm{m}$ 程度 と比較的厚く, 膜とチタンの界面に龟裂がみられる。一 方, IBDM 法による膜は $2 \mu \mathrm{m}$ 以下の薄膜であり, 膜と
チタン界面に黾裂がみられず強固に接着し9.101,プラス マ溶射法の欠点を克服していることがわかる。

(2)ウェットプロセス法

ウェットプロセス法の代表は電気化学的コーティング 法"1)であり, リン酸イオンおよびカルシウムイオンを含 む体液に近い緩衝溶液中で負の電位を印可することによ り数 $\mu \mathrm{m}$ のアパタイト膜を析出する方法である。この膜 は骨成分に近似した炭酸アパタイトを合むこと，微細な 形状の表面にもコーティングできることを特徵とする。

予備形成法は, 生体内アパタイト析出法と比較し, 骨 形成速度むよび骨との結合強度には優れるが, 膜の溶解, 剥離の問題が存在する。すなわち, これらのコーティン グ薄膜は、コーティングのままでは膜の結晶珄が低く体 液に対して溶解性が大きすぎる問題点がある。従来は, 電気妒による長時間加熱で結晶性を高めて溶解性を小さ くしてきたが, 膜の剥㒕の問題が解決されなかった。こ の奶策として，赤外線による $600 \sim 700^{\circ} \mathrm{C}$ で $10 \sim 20$ 秒 の急速加熱が Ti 基板との密着性を損なわず溶解性を制 御できる熱処理法であることが明らかとなっている12)。 リン酸カルシウム膜とチタンの密着性に重要な役割を果 たすのは，Ti-P 化合物の生成状況である（Fig. 5)。この 理由は, Ti-Ca 系では固溶体も化合物も形成しないが,
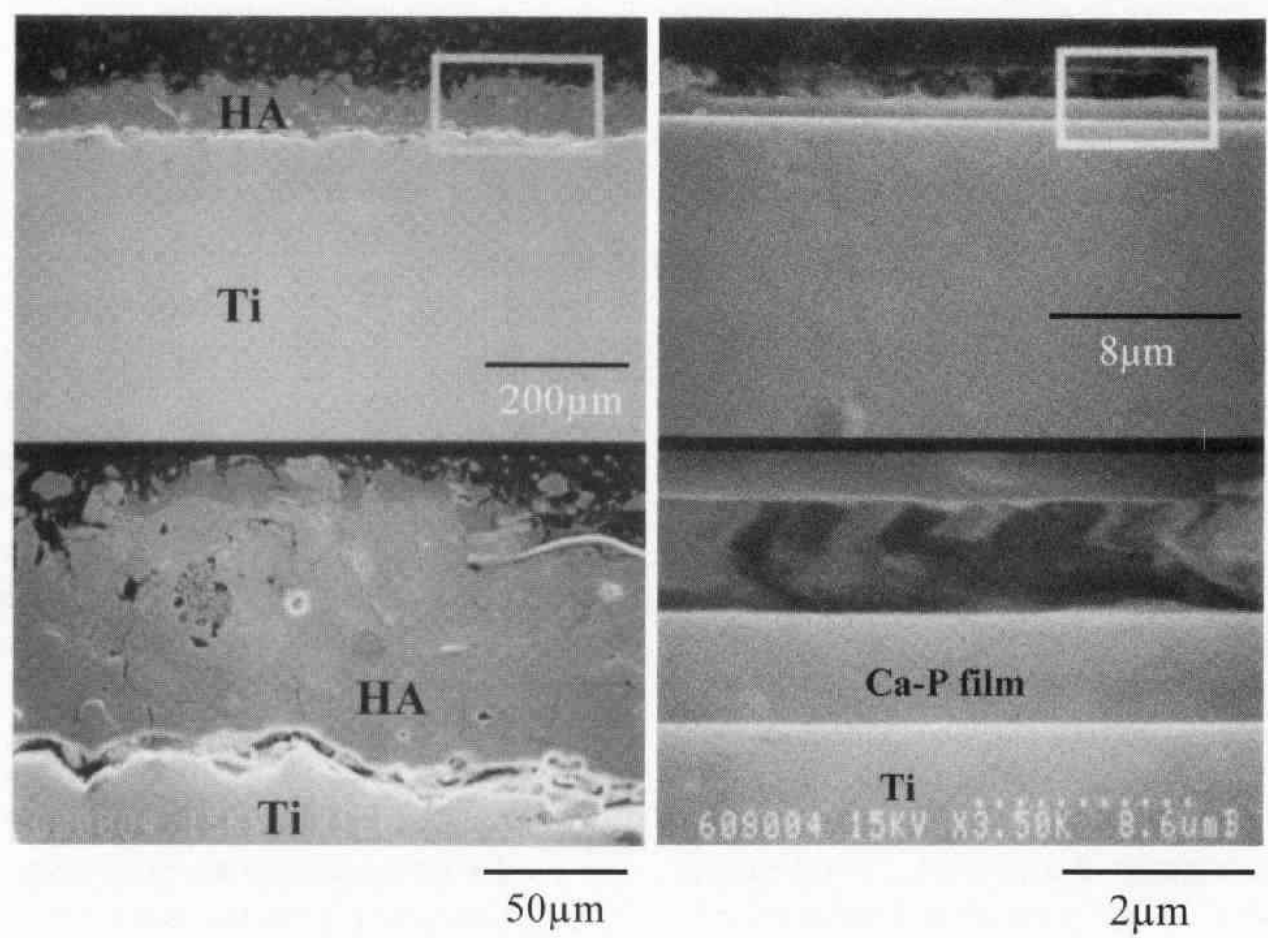

Fig. 4 Cross-section of Ca-P coatings produced by the plasma spraying method (left) and ion beam dynamic mixing method (right). 

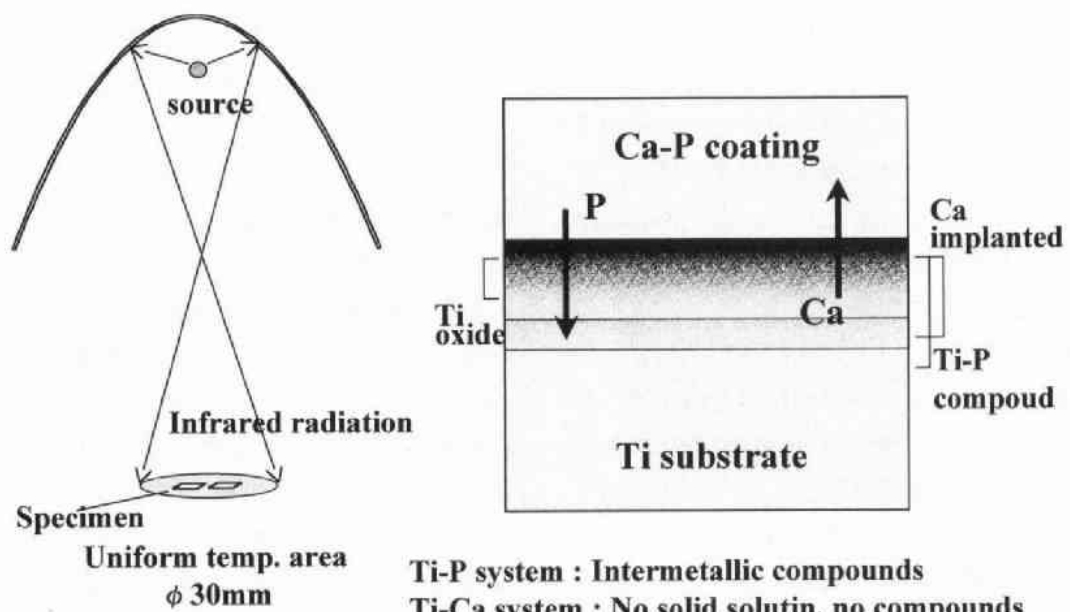

$\phi 30 \mathrm{~mm}$

Ti-P system : Intermetallic compounds

Ti-Ca system : No solid solutin, no compounds

Fig. 5 Rapid heating with infrared radiation to a thin Ca-P coatings on titanium.

Ti-P 系では多くの金属間化合物を形成するためである。

\section{3. 組織適合型インプランド, 3) (Fig. 6)}

現在の osseointegration 型インプラントは, 額骨の状 態が比較的健全な患者を対象としていたが，高䍅化社会 の到来とともに, 高数者队骨粗整症患者人も応用が可能 なインプラントの開発が求められている。「組織適合型
インブラント」は,このような状況のもと, 母床骨の条 件の悪い高訝者などに応用できる, 感染に伴う骨結合の 喪失を防ぐことを目的とし開発が進められているイン プラントであり, 現在 in vitro の基喽実伢がほぼ終了し in vivo の動物実験が行われている段階である゙。このイン プラントは, チタンを構造体として利用し, その表面の 形状および性状を改質することにより,骨組織接触部位,

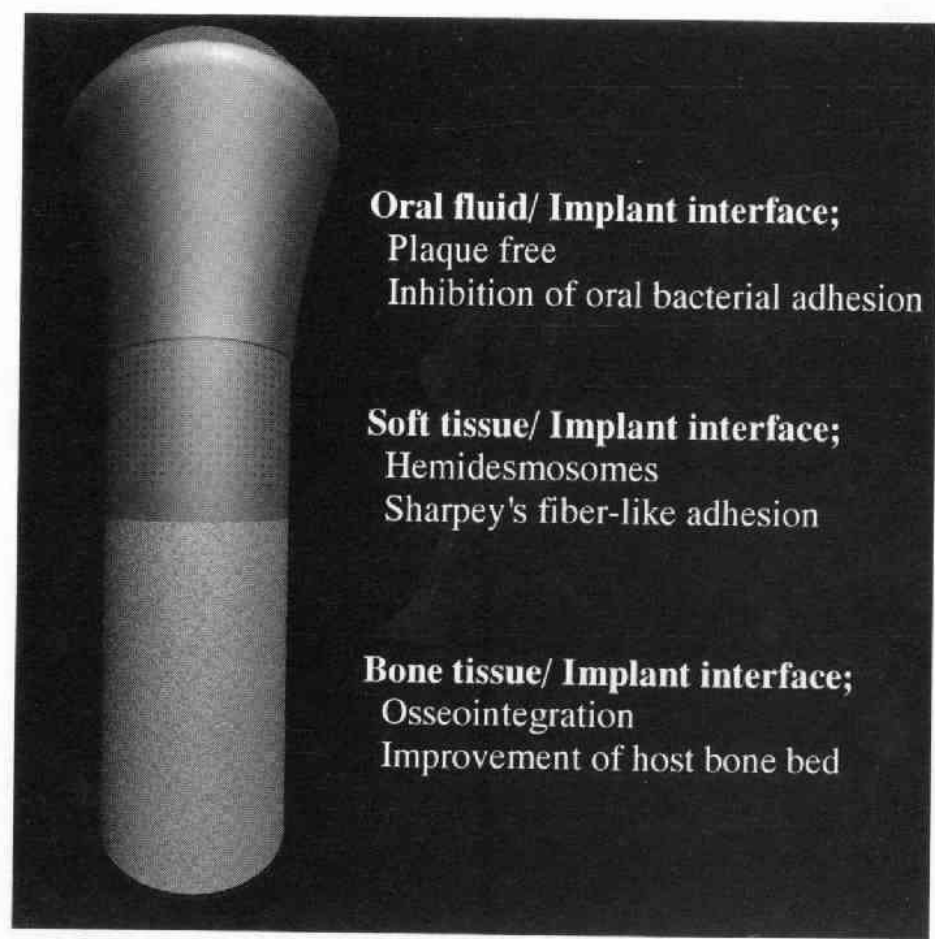

Fig. 6 Tissue-compatible dental implants. 
上皮下結合組織，上皮組織，および口腔内露出部位，全 てに適合する表面を持つことを特銜とする。この実現の ためには，骨組織と強固に結合するだけでなく，母床骨 を改善する, 天然菌と同様な軟組織接着槏式を持つ, 口 腔内露出部位ではプラークが付きにくい, などの要素が 必要である。以下, 接触する周囲組織ことに, インブラ ント材の表面改質法について概説する。

1）骨組織に接する部位

この部位の表面形状は, まず骨芽細胞の進展に適した Contact guidance を付与し ${ }^{131}$, 骨との接強面積を大きく する粗面を有することが必要である。

表面性状に関しては, 骨形成速度の增大, 強固な骨結 合を期待して, 骨形成終期には消失するようなりン酸力 ルシウム薄膜を形成する諸手段が有奻になろう。骨芽細 胞が多く存在する部位では必ずしも骨誘導は必要でな く，骨伝嫴性を有する表面で十分とも考えられる。

母床骨の改善にはより積極的に，骨芽綀胞を誘導する 骨形成タンパク（BMP: bone morphogenetic protein）を利 用しようとする試みが行われている。このためには、イ ンプラント体に強固に固定される担体 (carrier) の開発 が課題であり, 担体としてコラーゲンーアパタイト複合 体などが検討されている(1)。また, 骨粗数症の治撩薬で ある bisphosphonate をチタン表面に固定することによ り, 破骨細胞の抑制による母床骨の改善など, その局所 作用を期待した橡討が行われている ${ }^{15}$ 。

2）上皮下結合組織, 上皮と接する部位

天然歯に歯周炎が発症するように，インブラントには いわゆるインプラント周囲炎 (Peri-implantitis) が発拝 する。インプラント周囲炎では, 歯周炎と異なり, 周囲 溝は浅いがインプラントに沿った深い骨吸收が起こると いわれる。これらの原因は, 現在のインブラントが付着 上皮による結合機構および菌周組織でみられる防御機棰 を持たないためである。このように, 上皮下結合組織,
上皮のインプラント体への接着は, 骨吸収を防止するた めにも, 上皮や細菌の侵入の防止するためにも重要であ る。

現在まではこの部位を細菌の付着しにくい鏡面にし， 織維性結合組織の収縮により，物理的に封鎖するという 消拯的な手段に頼ってきた。今後は, 結合組織との確実 な接着を獲得し生物学的封鎖を達成するために, 線維芽 細胞, 上皮細胞の伸展, 伸張に影響する表面形状の制御 法が重要となる。そのために, 上皮細胞より線維芽細胞 の伸展が早いことを考虑した Contact guidance の設計, およびバクテリアと練胞のサイスの荤いを利用した表面 形状の設計が志向され，1 10 $\mu \mathrm{m}$ の microgroove をチタ ン表面に施すと同時に, 線維芽細胞が侵入する Critical なボアサイズである直径 50〜80 $\mu \mathrm{m}$ の孔を付与し，イ ンプラントと垂直に配向するシャーピー瀻維様接着を獾 得する努力がなされている゙。

表面性状の制御では, 軟組織接着を実現するために fibronectin やlaminin などの接着性タンパクでチタンを表 面修飾する方法が㛟討されている。細胞は元来, 細胞外 基質（ECM; extracellular matrix）と接着性タンパクを介 して接着していることから，インプラント体を ECM と みなすことにより，接着性タンパクを介した細胞接着が 可能となるからである (Fig. 7) ${ }^{16)}$ 。

3) 口腔内露出部位

インブラント周囲炎に罹患すると, Fig. 8 の X 線写真 に示されるように, インプラントを支持している implant fixture 上部周囲付近の骨の褧失がみられる。すなわち図 の矢印部は骨が吸收しているためX 線が透過している ことを示す。この原因の 1 つに細菌感染がある。インブ ラント周囲炎で撤去したインブラントのブラーク様付着 物には球状の連鍞球菌や細長い桿菌あるいはらせん状の スビロヘータ様の細菌付着が全面に観察される(Fig. 9)。 チタンは骨結合性に優れる反面, 口腔内細菌も付着しや

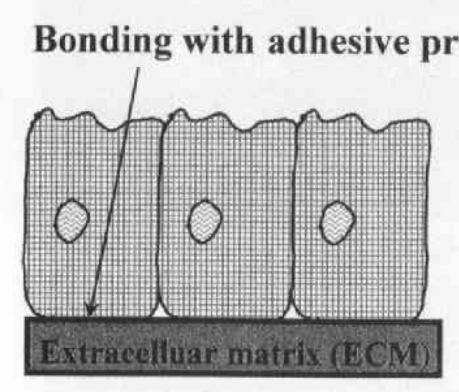

Epithelial tissue

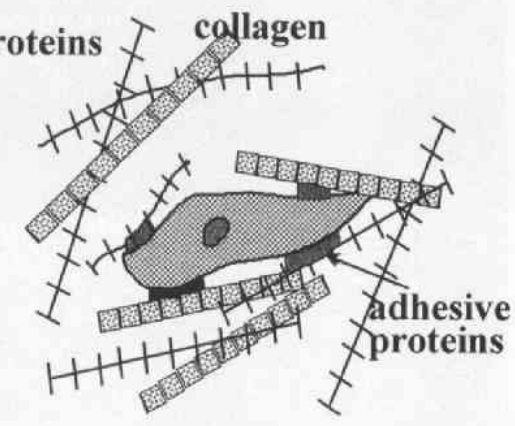

Connective tissue

Fig. 7 Cell adhesion to the extracelluar matrix through the adhesive proteins. ${ }^{16}$ ) 
すく，表面を鏡面にしようとも粗面にしようとも，若干 の量的差こそあれ細菌は付着しプラークが形成される。 チタンに細菌が付着しやすいのはチタンの osseointegration と関係がある。チタンは, 表面にリン酸カルシウム や血清タンパクが吸着しやすく, osseointegration 在獲得 しやすいといわれているが，このことは襄を返せば，口 腔内細菌も付着し易いことを意味する。

細菌は比表面積(単位質量当たりの表面積)が大きく,

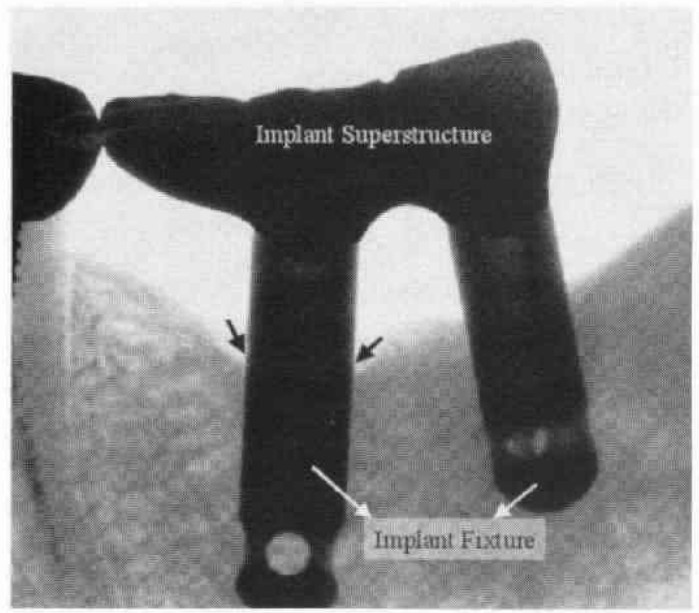

Fig. 8 Peri-implantitis.
その吸着特性は表面荷電状態に大きく影響される。した がって，この部位をブラークフリーの表面にするために は，表面荷電を考虑した衰面設計が必要となる。生息す る紐菌そのもの, あるいは細菌が付着する前段階として の獣液タンパクが付着しない表面改質法を検討する目的 で, 鏡面の純チタン板に, イオン注入処理 $\left(\mathrm{Ca}^{+}, \mathrm{N}^{+}\right.$, $\mathrm{F}^{+}$), 陽極酸化処理, チタニア低温溶射処理, イオンブ レーティング処理（TiN, Alumina）を施した"゙。これら の表面を持つ試料を, $\left.{ }^{3} \mathrm{H}\right]$-thymidine や $\left[{ }^{3} \mathrm{H}\right]$-uridine で ラベリンダした茵周病原菌を培養し, 初期付着特性を検 討した結果, Caイオン注入処理面で付着量が多く, Alumina 被膜処理面で特異的に少なくなり，表面電位およ びCaの存在が関与していることが示唆された2゙。さら に, 分注した上記培養菌液に各試験片を浸漬し, 生菌数 測定法による抗菌性を娭討した結果，Fイオン注入表面 で特異的に抗菌性が示され，これらの表面改質法により プラーク難付着性を有する表面を見出す可能性が示唆さ れた2。なおお,この部位は常時ブラッシングがなされる ことから，砷摩耗性に優れた表面でなくてはならない。

4. 歯根膜再建型インプラントとインテリジェ ントマテリアル

本来の粕根膜の機能，すなわち，歯牙を菌槽内に植立 し, 咬合時などのショックをやわらげる物理的機能，血 管を介して栄養を供給する機能，神経機能，を有する人

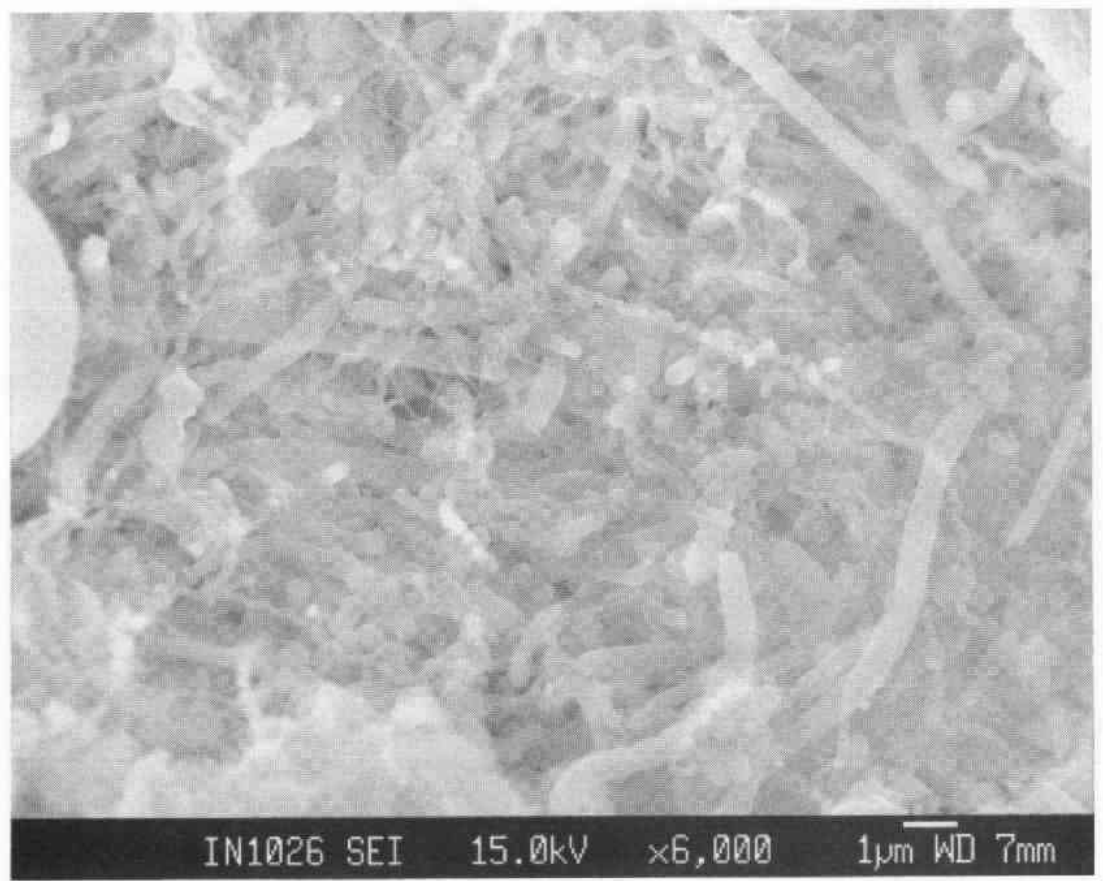

Fig. 9 Oral bacteria observed on the dental plaque around the peri-implantitis. 
工茵根膜の再建は卙科インプラントにとって永遠の課題 である。

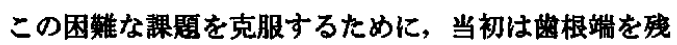
して拔去しチタンインプラントを埋入することにより菌 根膜槏組織の再生を意图した処置が試みられてきたが,

最近はより糟檑的な手法が研究されている。

その 1 つは前出した BMP などの機能性蛋白を担体, すなわち, ポリ乳䤒, ゼラチン, コラーゲンなどの複合 物に固定して利用する方法である。BMPが吸着し易い 担体を用い，一定のスペースを確保することにより橉根 膜が再生されるとの報告がある。

しかし, あらゆる組織の再生能を有する图根膜が失わ れた（因小素存在しない）インプラント体周囲㻴境で は霜根膜の再生はありえず, 移植・再植法を優先すべき との意見が多い。この現実を考虑すれば，インプラント 周囲での歯根膜の再生を可能とするには, 以下に示す方 法と再植法などの併用が有効となろう。すなわち, (1)個 人の霜根膜細胞を培坟するなどの細胞工学 (Tissue engineering)を革入する, (2TGF- $\beta$ フォミリー, Vitamin $D_{3}$, アメロジェニンなど機能性タンパクを, 道当な担体 (場 の確保, 吸收材) や㻴境（圧力など）を選択することに より応用する, (3)細胞接着技術を底用する,などにより 根膜再生型インプラントを開発することは夢ではなく なるに違いない。

最近, 温度, $\mathrm{pH}$ などの㻴境の変化に対応して, それ らを検出する「センサー機能」, 変化に応答し自较的に 判断する「プロセッサ機能」, そして修復, 成長, 分解 などの有効な処理を行う「エフェクタ機能」を併せ持つ インテリジェントマテリアルの開発が医学領域で行われ ている。この技街を利用し, 温度で薬物放出を ON-OFF する Drug Delivery System（DDS）や温度で親水性と瑓 水性を変化させる方法などが開発されるつつある ${ }^{18)}$ 。

表面は変幻自在であり, 材料表面にインテリジェント 機能を持たせることは至鹳である。しかし半楞体がナノ メータレベルを制御して製造されることを考えれば，高 度に制卸された生体に優しい表面を作り出すことは不可 能ではないと考えられる。歯科インプラント材が生体の 恒常性を乱さないインテリジェントマテリアルになる日 が訪れることを期待したい。

\section{文 献}

1) T. Inoue, J.E. Cox, R.M. Pilliar and A.H. Melcher: J. Biomed. Mater. Res. 21,107 (1987).

2) 吉成正雄, 井上 孝, 松坂蜸一, 水口 清, 見明康 雄, 加藤哲男, 田㥓雅和, 柴原孝喥, 矢岛安朝, 山 中すみへ，阿部伸一，下野正基 : 平成 8 年度, 平成 9 年度, 平成 10 年度東京歯科大学口腔科学研究セ ンターワークショッププログラム $(1997,1998,1999)$

3) M. Yoshinari: Transactions of 3rd International Congress on Dental Materials (1997) p. 70.

4) D. Steinberg, A. Klinger, D. Kohavi and M.N. Sela: Biomaterial 16, 1339 (1995).

5) 田中蛏男, 站川保則, 竹下文隆, 吉成正雄, 井上 孝, 大塚芳郎, 末次恒夫, 下野正基 : 日本歯科医学 会誌 17,94 (1998).

6) 今西泰彦, 吉成正雄, 北村 隆, 奥森直人, 五十謽 俊男, 井上 孝, 下野正基, 站川保則, 田中輝男 : 生体材料 16, 133 (1998).

7) T. Hanawa, H. Ukai and K. Murakami: J. Electron. Spectrosc. Relat. Phenom. 63, 347 (1993).

8) C. Ohtsuki, H. Iida, S. Hayakawa and A. Osaka: J. Biomed. Mater. Res. 35, 39 (1997).

9) M. Yoshinari, Y. Ohtsuka and T. Derand: Biomaterials 15, 529 (1994).

10) M. Yoshinari, B. Klinge and T. Dérand: Clin. Oral Impl. Res. 7, 96 (1996).

11) S. Ban and S. Marumo: Bioceramics 5, 49 (1992).

12) M. Yoshinari, Y. Watanabe, Y. Ohtsuka and T. Dérand: J. Dent. Res. 76, 1486 (1997).

13）井上 孝, 吉成正雄, 田中蟆男, 下野正基 : 表面技 街 49,682 (1998).

14) 田中順三 : 第 5 回つくばバイオマテリアル研究会挢 録集 (1998) p. 17.

15) M. Yoshinari, Y. Oda, H. Ueki and S. Yokose: J. Dent. Res. 77, 968 (1998).

16）林 正男 : “細胞接着分子の世界” (羊土社, 1995).

17) 宮山直也, 吉成正雄, 小田 豊 : 菊科材料 - 器械 18 , 109 (1999).

18) 岡野光夫 : BME 8, 22 (1994).

全般的 (材料を含む) 参考文献として “ロ腔インプラント学” 川原春幸監徏 (医蒋蓧出版, 東京, 1991).

材料と生体反応 (最新の情報がある) 参考文献として “インプラントの病理と臨床” 井上 孝, 武田武之 著, 下野正基監修 (日本菌科評論社, 東京, 1999). 